\title{
Non-Coding RNAs and Hereditary Hemorrhagic Telangiectasia
}

\author{
Anthony Cannavicci ${ }^{1,2}{ }^{-}$, Qiuwang Zhang ${ }^{2}$ and Michael J. B. Kutryk ${ }^{1,2, *}$ \\ 1 Institute of Medical Science, University of Toronto, Toronto, ON M5S 1A8, Canada; \\ a.cannavicci@mail.utoronto.ca \\ 2 Division of Cardiology, Keenan Research Center for Biomedical Sciences, St. Michael's Hospital, \\ Unity Health Toronto, University of Toronto, Toronto, ON M5B 1T8, Canada; \\ Qiuwang.Zhang@unityhealth.to \\ * Correspondence: Michael.Kutryk@unityhealth.to; Tel.: +1-(416)-360-4000 (ext. 6155)
}

Received: 14 September 2020; Accepted: 15 October 2020; Published: 17 October 2020

\begin{abstract}
Non-coding RNAs (ncRNAs) are functional ribonucleic acid (RNA) species that include microRNAs (miRs), a class of short non-coding RNAs ( 21-25 nucleotides), and long non-coding RNAs (lncRNAs) consisting of more than 200 nucleotides. They regulate gene expression post-transcriptionally and are involved in a wide range of pathophysiological processes. Hereditary hemorrhagic telangiectasia (HHT) is a rare disorder inherited in an autosomal dominant fashion characterized by vascular dysplasia. Patients can develop life-threatening vascular malformations and experience severe hemorrhaging. Effective pharmacological therapies are limited. The study of ncRNAs in HHT is an emerging field with great promise. This review will explore the current literature on the involvement of ncRNAs in HHT as diagnostic and pathogenic factors.
\end{abstract}

Keywords: non-coding RNAs; microRNAs; long non-coding RNAs; hereditary hemorrhagic telangiectasia; biomarkers; endothelial cells; angiogenesis

\section{Introduction}

Hereditary hemorrhagic telangiectasia (HHT) is a rare genetic vascular disorder inherited in an autosomal dominant fashion. On average, approximately one in 5000 to 8000 people are affected, while the founder effect has contributed to a higher prevalence in certain regions, such as the Netherlands Antilles, Jura in France and Funen in Denmark [1]. Vascular malformations in HHT include skin and mucocutaneous telangiectasias, and pulmonary, cerebral, hepatic and spinal arteriovenous malformations (AVMs) [2,3], all of which are susceptible to rupture with resultant spontaneous hemorrhage. Epistaxis is the most common symptom and is present in approximately $95 \%$ of patients $[4,5]$. HHT is a progressive disorder with significant morbidities and mortality, and lacks a universally effective pharmacological therapy [2].

HHT is caused by heterozygous mutations in at least three known genes: endoglin (ENG, chromosomal locus 9q34) [6], activin receptor-like kinase 1 (ACVRL1, also known as ALK1, chromosomal locus 12q1) [7] and mothers against decapentaplegic homolog 4 (SMAD4, chromosomal locus 18q21) [8]. Each gene encodes for a protein in the transforming growth factor beta (TGF $\beta$ )/bone morphogenetic protein (BMP) signaling pathway. This pathway is responsible for many cellular functions, including growth, differentiation and apoptosis, and is critical in angiogenesis and normal endothelial cell (EC) function [9]. The pathogenic role of these genes has been demonstrated in the adult mouse where the homozygous knockout of $E N G, A C V R L 1$ or SMAD4 resulted in various vascular defects, including AVMs $[10,11]$. ENG encodes for a TGF $\beta$ co-receptor that enhances the affinity of ligand binding to TGF $\beta$ I and II receptors. This co-receptor is predominately expressed on the endothelium, 
activated monocytes and macrophages [2]. ACVRL1 encodes for a TGF $\beta 1$ receptor that is predominately expressed on endothelial, lung and placental cells [2]. Mutations in ENG and ACVRL1 result in HHT1 and HHT2, respectively, and on average display distinct clinical manifestations, but overlap is not uncommon. Sabbà et al. demonstrated a higher prevalence of pulmonary $(75.5 \%$ vs. $44.1 \%)$ and cerebral AVMs (20.9\% vs. $0 \%$ ) in HHT1, while liver manifestations were higher in HHT2 (83.1\% vs. $60 \%)$ [12]. SMAD4 is a signal transducer in the TGF $\beta$ signaling pathway that directly regulates gene expression. Mutations in SMAD4 not only result in HHT, but juvenile polyposis (JP), culminating in a combined syndrome designated as JP/HHT [8]. ENG and ACVRL1 mutations are responsible for $90 \%$ of HHT cases, while SMAD4 contributes to only $2 \%[13,14]$. A small percentage of cases have been attributed to novel disease loci, HHT 3 (chromosomal locus 5q31) [15] and HHT 4 (chromosomal locus 7p14) [16], but these genes have yet to be identified. Over 700 pathogenic mutations have been identified in ENG and ACVRL1 patients (https://arup.utah.edu/database/HHT/, access date: 20/04/2020), comprising single base pair changes, large deletions, duplications, substitutions and missense mutations $[13,17]$. Interestingly, disease severity and the presentation of clinical manifestations vary drastically between patients and this is further demonstrated in affected family members. This discrepancy suggests that the genetic mutations alone are not entirely responsible for disease characteristics and raises the question: what other biological factors could be at play?

Non-coding RNAs (ncRNAs) are functional ribonucleic acid (RNA) sequences that are transcribed from DNA, but not translated into protein. NcRNAs can be divided into three categories based on their length: (1) ncRNAs longer than 200 nucleotides (nts), including ribosomal RNA (rRNA), long non-coding RNA (lncRNA) and circular RNA (circRNA); (2) ncRNAs shorter than 200 nts, but longer than $40 \mathrm{nts}$, such as transfer RNA (tRNA), small nucleolar RNA (snoRNA), Ro-associated Y RNA (YRNA) and small nuclear ribonucleic acid RNA (snRNA); and (3) ncRNA shorter than 40 nts like microRNA (miRNA), piwi-interacting RNA (piRNA), short interfering RNA (siRNA) and tRNA-derived small RNA (tsRNA) [18]. NcRNAs regulate gene expression at the transcriptional and post-transcriptional levels, and are involved in a wide array of cellular processes. In particular, snRNAs and snoRNAs are involved in mRNA maturation; rRNAs and tRNAs are important components for protein translation and miRNAs, piRNAs and lncRNAs are involved in the regulation of target gene expression.

MiRNAs (miRs) are the best studied group of noncoding RNAs. They were first described in 1993 by the Ambros and Ruvkun groups and have since caused a paradigm shift in how we understand biological processes $[19,20]$. Over 2000 miRs have been identified and it has been postulated that they regulate $30 \%$ of known genes $[20,21]$. Processed by endonucleases, the single-stranded miRs bind to cognate mRNAs to induce translational silencing by altering transcript stability or impacting mRNA translation. A single miR can have multiple mRNA targets. MiRs are involved in almost every cellular process [22] and play a role in a wide range of human diseases [22,23]. They have been proven to have reliable diagnostic and prognostic attributes [24], especially in oncology, and are being pursued as potential therapeutic targets $[25,26]$. A growing class of miRs known as "angio-miRs" have also been shown to contribute to vascular diseases [27]. Given that HHT is a disorder characterized by vascular dysfunction, it is possible that "angio-miRs" play a role in HHT pathogenesis. However, the exact role of any class of miR has yet to be fully characterized in HHT. In this review, we discuss our current understanding of the involvement of ncRNAs in HHT as circulating biomarkers, pathogenic factors and the potential for ncRNAs as therapeutic targets.

\section{MiR Biogenesis and Mechanisms of Action}

Nearly half of all identified miRs are expressed from specific genes with their own promoters, with the remainder from protein-coding genes [28,29]. Additionally, multiple miRs may be expressed as a single transcript, defined as families or clusters, and share similar target homology [30]. Canonical miR biogenesis is initiated with miR gene transcription by an RNA polymerase II [31]. The result is an $\sim 80$ nucleotide stem-loop structure called a primary $\mathrm{miR}$ (pri-miR) [32]. The pri-miR is further 
processed by an RNase III enzyme and a double-stranded RNA-binding protein (dsRBP), called Drosha and DGCR8, respectively [32]. This complex shortens the pri-miR to $\sim 70 \mathrm{nts}$ to generate the pre-miR. The pre-miR is exported from the nucleus to the cytoplasm where it is once again processed by an RNase III enzyme and dsRBP, Dicer and transactivation-responsive (TAR) RNA-binding protein (TRBP), respectively, effectively removing the hairpin to produce a miR-miR duplex [32,33]. The duplex comprises a passenger strand and a guide strand. The passenger strand is degraded, while the guide strand is incorporated into the RNA-induced silencing complex (RISC). Strand incorporation is dependent on the thermodynamic stability of the $5^{\prime}$ end of the miR-miR duplex, where the less stable strand is incorporated [34]. RISC contains an RNA binding protein responsible for miR silencing activity, Argonaute 2 (AGO2). AGO2 has potent RNase-H-like endonuclease activity and is capable of cleaving mRNAs [35].

MiRs guide the RISC-AGO complex to target mRNAs by recognizing the miR response element (MRE) in the $3^{\prime}$ untranslated region (UTR) [36,37]. Alterative binding sites have been identified in the $5^{\prime}$ UTR, coding sequences and within promoter regions [37]. Base pair complementarity between miRs and MREs dictates the mode of gene silencing. Perfect complementarity activates AGO2's endonuclease activity, resulting in the cleavage and subsequent degradation of target mRNAs [35]. However, in metazoans, this rarely occurs and the majority of miR-MRE interactions are not perfectly complementary [38]. In this scenario, translational inhibition can occur where the miR-RISC-AGO complex likely blocks translational machinery from binding. Alternatively, proteins in complex with AGO2 can recruit poly(A)-deadenylases to elicit mRNA degradation [38]. In this way, miRs can regulate the expression of tens to hundreds of mRNAs. Bioinformatic analyses can use algorithms to predict complementarity for the identification of hundreds of mRNA targets per miR, but realistically only a small subset are experimentally validated [21]. It is important to note that individual miR activity is dependent on several factors, including miR tissue expression profiles (tissue-specific vs. housekeeping) and miR expression levels. Typically, higher miR expression will have a more robust effect on target mRNAs.

\section{Circulating MiR Biomarkers in HHT}

The discovery of circulating miRs was achieved by several groups [39-41], most notably by Chim et al. who identified that stable plasma miRs could distinguish between pregnant and non-pregnant women [42]. Since then, circulating miRs have been established as stable and sensitive candidate biomarkers for various diseases, including cancers, cardiovascular diseases and neurological disorders [43-46]. The stability of circulating miRs can be attributed to their association with proteins such as AGO2 [47] and lipoproteins [48] or their containment in extracellular vesicles [49]. In this way, miRs are shielded from RNase enzymes and are stable in blood for up to $24 \mathrm{~h}$ [50]. Changes in circulating miR levels have been shown to be extremely sensitive to disease conditions and can outperform conventional biomarkers. For example, changes in circulating miR levels in response to disease states have been shown to be more rapid than those of mRNAs or proteins [46,51]. Oerlemans et al. demonstrated that changes in circulating miRs were detected earlier compared with that of troponin for the diagnosis and management of acute coronary syndrome [52].

HHT is diagnosed in combination by a clinical criteria known as the Curaçao criteria [53] and the molecular detection of known genetic mutations. Due to loci heterogeneity, technical challenges of molecular diagnostic techniques and de novo mutations, a clinical diagnosis is always required [53]. Additional biomarkers would greatly improve the diagnostic process as HHT is actually underdiagnosed [54]; they could also aid in the detection and management of clinical manifestations. The detection of AVMs is critical for the management of patient well-being. Approximately $50 \%$ of patients develop pulmonary AVMs (PAVMs), 80\% develop hepatic AVMs (HAVMs), 10\% develop cerebral AVMs (CAVMs) and 1\% develop spinal AVMs (SAVMs) [2,55]. All AVMs are susceptible to rupture that can cause numerous life-threatening complications, including hemorrhagic and ischemic stroke, air embolism, congestive heart failure, cerebral abscess and seizure $[55,56]$. The timely detection 
of AVMs is critical to prevent serious and life-threatening complications, but current diagnostic screens are costly, relatively inaccessible and expose patients to unhealthy doses of radiation [57]. Circulating miRs could potentially provide a rapid, inexpensive, safe and relatively non-invasive screening test for the diagnosis of AVMs.

\subsection{Elevated Circulating MiR-210 and PAVMs in HHT}

A previous study from our laboratory identified a candidate circulating miR biomarker for the detection of PAVMs in HHT patients. Plasma miRs from HHT patients with PAVMs and healthy controls were profiled with a microarray analysis and a total of eight miRs were found to be dysregulated [58]. Select miRs identified by the array were validated with a reverse transcription quantitative polymerase chain reaction (RT-qPCR) and miR-210 was found to be significantly upregulated in plasma from HHT patients with PAVMs [58]. Additionally, miR-210 is a well characterized "hypoximir" that is robustly expressed in ECs under hypoxia $[59,60]$. The increased levels of circulating miR-210 identified in our study may be a result of PAVM-induced hypoxemia. It is also possible that this phenomenon may be a compensatory mechanism since EC overexpression of miR-210 has been shown to augment angiogenesis and tube formation [61]. Our study successfully identified a novel circulating miR biomarker that can potentially detect HHT patients only with PAVMs. However, it is necessary to improve the validity of this biomarker with a more clinically relevant sample size. Future work will aim to measure circulating miR-210 levels in HHT patients with treated PAVMs. Presumably, once an AVM is treated, typically by coil embolization, associated symptoms like hypoxemia should disappear. If miR-210 is in fact induced by hypoxia, then its levels should return to baseline once a PAVM has been treated. If this is the case, miR-210 stands to be an extremely sensitive and reliable biomarker for the detection of PAVMs in HHT.

\subsection{Dysregulated Levels of Circulating MiR-205 and MiR-27a in HHT}

Tabruyn et al. were the second to identify circulating miR dysregulation in HHT [62]. They conducted a miR microarray analysis on plasma from four HHT patients (two HHT1 and two HHT2) and identified 34 dysregulated miRs; 32 were upregulated, while two were downregulated. MiR-205 and miR-27a were selected for RT-qPCR validation in 24 HHT patients (11 HHT1 vs. 13 HHT2) and 16 controls. It was found that miR-205 was significantly decreased and miR-27a was significantly increased in HHT patient plasma. There were no significant differences between the expression of these miRs between HHT1 and HHT2 patients. This consistency highlights the potential of miRs as ideal candidates for the diagnosis of HHT.

MiR-27a is relatively well characterized and has been implicated in EC function [62,63], angiogenesis [63,64] and cancer [65]. Interestingly, a recent study has shown that miR-27a is hypoxia inducible [66]. Therefore, it is possible that the observed increase may be a result of HHT-related hypoxemia. However, Tabruyn et al. did not describe the clinical characteristics of enrolled patients. It would be interesting to explore the role hypoxia may play with regard to increased levels of miR-27a. Additionally, miR-27a has many putative targets in the TGF $\beta$ pathway, including SMADs (1/4/5/2), TGF $\beta R I$, ZEB2 and SP1 $[67,68]$ (Figure 1). Future research should experimentally validate these targets in ECs. The involvement of miR-205 in angiogenesis and EC function is not well characterized; one study demonstrated that miR-205 regulates the expression of integrin $\beta 4$, a major component of EC gap junctions [69]. Additionally, miR-205 has been shown to be involved in TGF $\beta$ signaling where it targets downstream transcription factors ZEB2 and SIP1 [70]. MiR-205 was shown to negatively respond to TGF $\beta 1$ stimulation in epithelial cells [71]. Tabruyn et al. further characterized the role of miR-205 in human umbilical vein endothelial cells (HUVECs). Overexpression of miR-205 in HUVECs decreased proliferation, migration and tube formation, while inhibition resulted in the opposite. Additionally, they described a role of miR-205 as a regulator of TGF $\beta$ signaling by targeting SMAD4 and SMAD1. They also demonstrated that miR-205 overexpression led to a significant increase in PAI-1 and a significant reduction in ID-1 mRNA levels. TGF $\beta$ signaling can be transduced by ALK1 and 
ALK5 pathways, where the former leads to EC activation, and the latter, EC quiescence. The effects of ALK1 and ALK5 signaling can predominately be attributed to the expression of PAI-1 and ID-1, respectively. They postulated that the observed reduction of circulating miR-205 levels is a result of reduced ALK1 signaling. They further suggested that the observed increase in circulating miR-27a is due to an increase in ALK5 signaling. This is based on the notion that an increase in ALK5 signaling is due to the reduction of ALK1 signaling in HHT. However, it has been demonstrated that ALK1 and ALK5 signaling maintain a very fine balance; if one pathway was reduced, the other would be equally reduced [9]. This was demonstrated in ECs cultured from HHT patient blood, known as blood outgrowth endothelial cells (BOECs) [72], and in ENG heterozygous mouse embryonic stem cells [73]. Thus, it is possible that the observed decrease and elevation in circulating miR-205 and miR-27a, respectively, may be the result of an alternate mechanism.

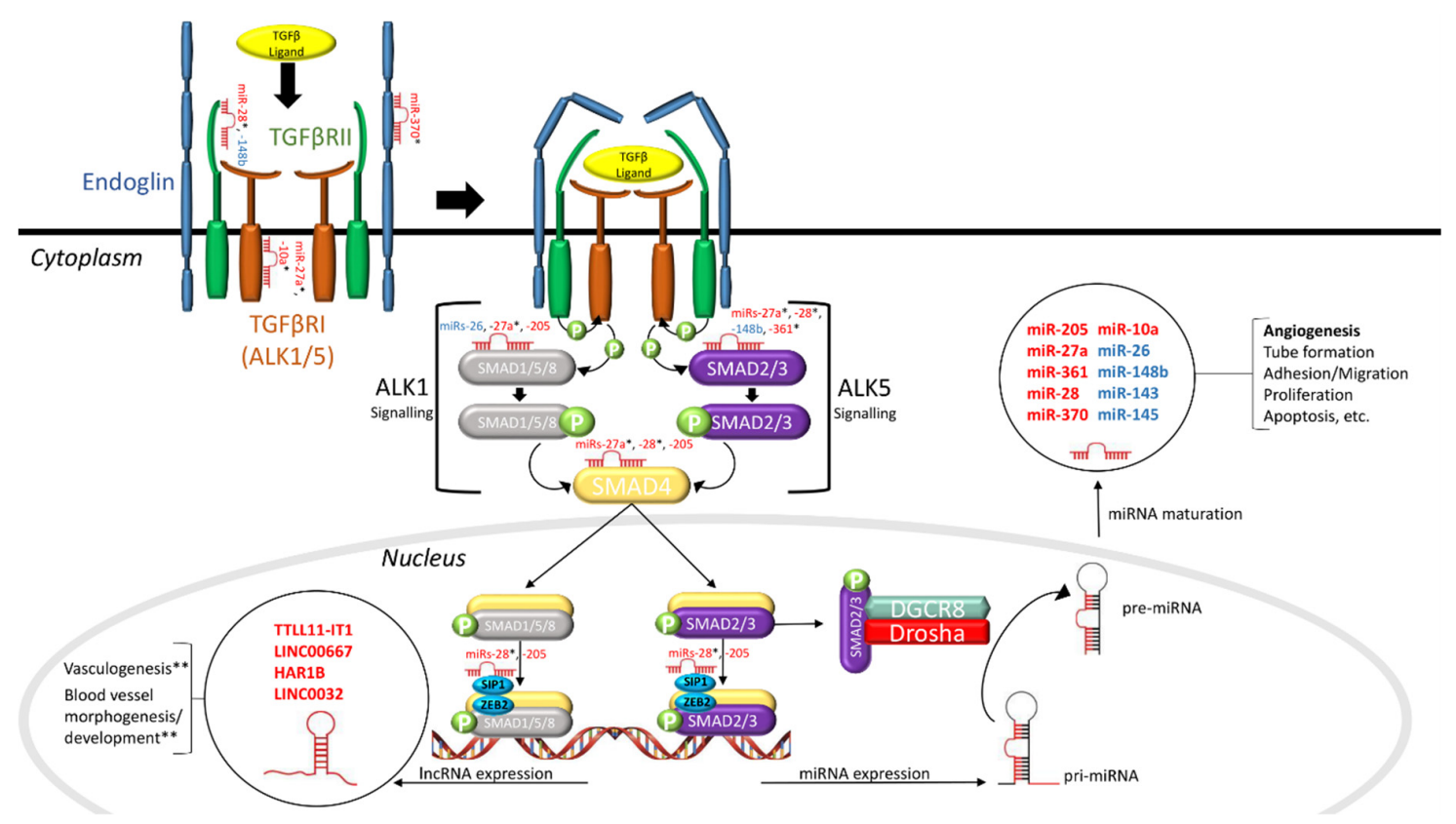

Figure 1. Interactions between non-coding RNAs and the TGF $\beta$ signaling pathway in hereditary hemorrhagic telangiectasia (HHT). As shown in this schematic diagram, dysregulated microRNAs (miRs) (in red) identified in HHT patients directly target a number of TGF $\beta$ signaling molecules, including SMADs and TGF $\beta$ Rs, and dysregulated lncRNAs (in red) found in HHT patients have a purported role in regulating vasculogenesis and vessel morphogenesis and development. SMAD2/3 can alternatively incorporate with the microprocessor complex to regulate the processing of pri-miRNA to pre-miRNA. Aberrant TGF $\beta$ signaling has been found to result in the altered expression of various miRs (in blue) that are involved in angiogenesis. The interaction between non-coding RNAs and TGF $\beta$ signaling establishes a narrative for their involvement in HHT pathogenesis. TGF $\beta$ : transforming growth factor beta; TGF $\beta$ RI/II: TGF $\beta$ receptor I/II; ALK1/5: activin receptor-like kinase 1/5; miRNA: microRNA; lncRNA: long non-coding RNA; SMAD1/2/3/4/5/8: mothers against decapentaplegic homolog 1/2/3/4/5/8; SIP1: Smad interacting protein 1; ZEB2: zinc finger e-box binding homeobox 2; DGCR8: DiGeorge syndrome critical region gene 8; pri-miRNA: primary miRNA; pre-miRNA: precursor miRNA; "P": phosphoryl group (* putative targets, ${ }^{* *}$ predicted by bioinformatics).

\subsection{Dysregulated Circulating MiR-370 and MiR-10a in HHT1 and HHT2}

Recently, Ruiz-Llorente et al. further identified dysregulated circulating miRs in HHT patient plasma [74]. In this study, the authors employed a miR-target prediction algorithm to specifically identify miRs that target ENG and/or ALK1. From the analysis, miR-370 and miR-10a were highly predicted to target ENG and ALK1, respectively, and miR-214 was highly predicted to target both ENG and ALK1. These miRs were selected for RT-qPCR validation in 34 HHT patients (17 HHT1 
vs. 17 HHT2) and 16 controls. It was found that miR-370 was significantly decreased only in HHT1 patients compared with HHT2 patients and controls, while miR-10a was significantly increased only in HHT2 patients compared with HHT1 patients and controls. MiR-214 was not found to be significantly dysregulated.

MiR-370 has been experimentally validated to target ENG in ovarian cancer cells [75], yet its role in EC function and angiogenesis is unclear, as multiple reports have demonstrated conflicting evidence. Overexpression of miR-370 inhibited proliferation, migration and tube formation in human dermal microvascular ECs, retinal capillary ECs and HUVECs [76,77]. In contrast, miR-370 overexpression was shown to promote HUVEC proliferation, migration and tube formation to facilitate healing after finger amputation [78]. Additionally, miR-370 suppression by circular RNA circ_0003204 inhibited the proliferation, migration and tube formation of human aortic ECs [79]. It is unclear why this discrepancy exists, but suggests a far more complex role of miR-370 in EC function. MiR-10a has been shown to have anti-angiogenic effects in mouse umbilical vein ECs by targeting $\beta$-catenin [80]. It has also been shown to regulate VCAM1 expression in ECs under hemodynamic force by targeting GATA6 [81]. Therefore, an exact functional role in HHT pathogenesis remains unclear, but their potential as diagnostic biomarkers in HHT shows great promise. The ability of these miRs to distinguish between HHT1 or HHT2 patients could greatly improve the diagnostic process, as a number of HHT patients are asymptomatic or lack a known genetic mutation. Further research is required to validate these miRs in a more clinically relevant sample size and to directly confirm that these miRs indeed target ENG and ALK1 in ECs.

\section{MiRs as Pathogenic Factors in HHT}

MiRs have been demonstrated to play a pathogenic role in a variety of human diseases, including cancer, cardiovascular disease, autoimmune diseases and inflammatory diseases [22,23]. MiR profiling analyses have identified a plethora of up- and downregulated miRs in numerous types of cancers [24]. It has been shown that overexpressed miRs can act as "oncomiRs" by targeting tumor suppressors or by promoting proliferation and inhibiting apoptosis [82]. Additionally, the downregulation of certain "tumor suppressor" miRs, such as let-7, can also contribute to cancer pathogenesis [83,84]. A growing class of miRs known as "angio-miRs", predominately expressed in ECs and responsible for the regulation of angiogenic processes, have also been shown to contribute to cancer and cardiovascular disease [27]. Given that HHT is a disorder characterized by angiogenic and EC dysfunction, it would not be surprising if dysregulated "angio-miRs" played a role in disease pathogenesis. There are numerous studies that have identified the involvement of miRs in TGF $\beta$ signaling. They have demonstrated that various components of the TGF $\beta$ pathway are targeted by miRs and that the pathway itself regulates miR biogenesis [85].

\subsection{Canonical TGF $\beta$ Signaling in HHT}

The TGF $\beta$ signaling cascade is initiated with the TGF $\beta$ superfamily of ligands (TGF $\beta 1 / 3$, BMPs, activin) binding in complex to two cell surface receptors; Type I (RI), such as ALK1/5, and Type II (RII) [86] (Figure 1). Upon ligand binding, these receptors form a heteromeric complex, activating their serine/threonine kinase activity [86]. Endoglin is an auxiliary co-receptor that can interact with the RI-RII-ligand complex to enhance ligand affinity [87]. Subsequently, RII will trans-phosphorylate RI, which in turn will phosphorylate the family of receptor-regulated SMADs (R-SMAD 1/2/3/5/8) [88]. The TGF $\beta$ pathway can propagate the signal through two cascades: SMAD1/5/8 or SMAD2/3. ALK1 signals through SMAD1/5/8, leading to EC activation $[9,13]$. ALK5 propagates the signal through SMAD2/3, leading to EC quiescence $[9,13]$. It has been shown that endoglin enhances the SMAD1/5/8 pathway and inhibits the SMAD2/3 pathway. Cascade selection is determined by the combination of ligand and receptors. Regardless of the selected cascade, both groups of R-SMADs interact with a common partner SMAD (Co-SMAD) known as SMAD4 [88]. This complex of R- and Co-SMADs translocates to the nucleus where it regulates the transcription of target genes [88]. 


\subsection{Drosha and HHT Pathogenesis}

Drosha is part of a protein complex called the microprocessor that is responsible for the cleavage of pri-miR into pre-miR [89]. The silencing of Drosha in HeLa cells results in the aggregation of pri-miRs and a decrease in pre-miRs [90]. Drosha is fundamental in the biogenesis of almost all miRs, but has also been shown to be involved in the regulation of mRNAs [90]. A few studies have demonstrated that Drosha can bind and cleave mRNAs, and can also associate with promoter regions to regulate specific genes [91-93]. In the TGF $\beta$ pathway, SMAD2/3 has been shown to incorporate with the microprocessor complex to regulate target miR genes [82,91] (Figure 1).

Kuehbacher et al. demonstrated that the knockdown of Drosha in HUVECs had a minimal effect on EC migration, viability and tube formation [94]. In vivo analysis of Drosha knockdown in a matrigel plug did not reveal significant effects on sprouting angiogenesis [94]. Even though Drosha knockdown had an insignificant effect on angiogenesis and EC function it reduced the expression of 29 miRs by 30\% [94]. It is possible that the knockdown of Drosha activated compensatory mechanisms that mitigated its effects on EC function and angiogenesis. An inducible EC-specific knockout mouse model of Drosha would certainly provide a more robust analysis.

A study by Jiang et al. identified a higher prevalence of Drosha mutations in an HHT population and generated robust Drosha knockout animal models. Exome sequencing was performed on a total of 98 individuals; 23 confirmed HHT patients and 75 probands suspected to have HHT who lacked known pathogenic mutations [95]. Three heterozygous Drosha mutations (P32L, P100L and K226E) were detected in seven of the 98 individuals ( 7\%) compared with $0.04 \%$ in the general population [93]. An additional Drosha mutant (R279L) was found in a separate HHT family [93]. These Drosha mutants were analyzed in mouse embryonic fibroblasts (MEFs); interestingly, only the P100L and R279L mutants were shown to reduce expression of specific miRs, by approximately $17 \%$ and $35 \%$, respectively, compared to wild type (WT) [95]. P100L and R279L were introduced into zebrafish embryos to investigate their angiogenic functions. Zebrafish with these two mutants developed vascular defects, including vascular permeability and a reduction of vascular density [95]. An EC-specific inducible knockout Drosha mouse model also demonstrated vascular permeability, disorganized vasculature and, interestingly, intestinal bleeding [95]. However, no AVMs were detected in either animal model [95].

The presence of Drosha mutations in HHT populations may contribute to disease pathogenesis and the observed clinical spectrum. BOECs derived from HHT patients with Drosha mutations may be a robust cellular model to profile and characterize affected miRs and mRNAs. Drosha itself has also been shown to regulate gene expression directly [90]. It would be interesting to identify Drosha-targeted genes and elucidate how they may contribute to HHT pathogenesis.

\subsection{MiRs and HHT Pathogenesis}

Few studies have characterized the role of miRs in HHT pathogenesis. However, numerous miRs have been identified to be regulated by and target components of the TGF $\beta$ pathway in a variety of tissues and disease conditions [85]. MiR-26 has recently been shown to be involved in vascular stability, where its knockdown in zebrafish led to vascular hemorrhage [96]. MiR-26 from ECs can regulate vascular smooth muscle cell (VSMC) differentiation in a paracrine manner [96]. It was shown that a decrease in miR-26 leads to an increase in its target, SMAD1, resulting in VSMC dysregulation and hemorrhage [96]. Another study demonstrated that the overexpression of miR-148b can improve migration, proliferation and angiogenesis in HUVECs by targeting SMAD2 and TGF $\beta$ RII [97]. Subsequently, wound vascularization and healing were greatly augmented by a miR-148b mimic in a wound-healing mouse model [97]. MiR-148b inhibition greatly impaired wound healing, which was rescued by silencing SMAD2 [97]. A separate study demonstrated that VSMCs could regulate EC function via TGF $\beta$-mediated secretion of miRs-143/145 [98]. Co-culture of VSMCs overexpressing miRs-143/145 with ECs greatly impaired EC function, while inhibition of 
the TGF $\beta$ pathway reversed this effect [98]. This study demonstrates how VSMCs can regulate EC activation/quiescence through the secretion of miRs in a TGF $\beta$-dependent manner [98].

A previous study from our laboratory identified significantly decreased levels of miR-361-3p and miR-28-5p in peripheral blood mononuclear cells (PBMCs) derived from HHT patients [99]. PBMCs are mostly comprise lymphocytes and monocytes [100]. The pathogenic potential of PBMCs has been demonstrated in HHT1 mouse models. It has been shown that dysregulated TGF $\beta$ signaling adversely affects PBMC migratory capacity, which contributes to vascular dysplasia and prolonged inflammation [101,102]. The mRNA level of insulin-like growth factor 1 (IGF1), a putative target of miR-28-5p and miR-361-3p, was shown to be significantly upregulated in HHT patient-derived PBMCs. However, IGF1 plasma protein levels were not significantly different between patients and controls. It is possible that IGF1 could be overexpressed at angiogenic or inflammatory sites rather than systemically, contributing to the development of vascular dysplasia. IGF1 has been shown to play a significant role in augmenting angiogenesis in vitro and in vivo [103]. A previous study demonstrated that miR-361-3p is involved in the function of proangiogenic Tie2-expressing monocytes by targeting IGF1 [104]. MiR-28-5p has been shown to directly target IGF1 in hepatocellular carcinomas [105] and liver cancer stem cells [106]. Additionally, miR-28-5p and miR-361-3p have multiple putative targets in the TGF $\beta$ pathway, including SMADs, TGF $\beta$ RII and SP1 [66,67] (Figure 1). It is possible that the observed decrease in miR-28-5p and miR-361-3p and increase in IGF1 may be a compensatory mechanism in response to reduced TGF $\beta$ signaling. Further research is required to understand the role these miRs play in PBMC dysfunction and ultimately HHT pathogenesis.

\section{LncRNAs and HHT}

LncRNAs are non-coding RNA species that are greater than 200 nucleotides in length and regulate gene expression post-transcriptionally [18]. LncRNAs can be divided into two functional groups based on their sub-cellular localization: (1) nuclear and (2) cytoplasmic. Nuclear lncRNAs can influence gene expression via various mechanisms, including chromatin remodeling, protein sequestration and the enhancement or dampening of promoter activity [107]. One of the ways that cytoplasmic lncRNAs can influence gene expression is by regulating the availability and stability of miRs by acting as miR "sponges" [107]. Although lncRNA mechanisms have been well characterized, evidence suggests that most lncRNAs are non-functional [107]. Nonetheless, a few lncRNAs have been implicated in vascular and endothelial cell biology. For example, the lncRNA MALAT1 was shown to promote EC proliferation and migration under hypoxic conditions [108]. Conversely, MEG3 was demonstrated to inhibit EC proliferation, survival and tube formation [108]. Singh et al. were the first to identify differential expression of lncRNAs in TGF $\beta 1$-stimulated HUVECs [109]. They demonstrated that 2051 and 2393 lncRNAs were significantly upregulated and downregulated, respectively. Of these, MALAT1 was upregulated the most ( 220-fold), contributing to its role in EC biology. Given the functional relevance of lncRNAs in EC biology, one would assume that they may play a role in HHT. Indeed, Tørring et al. sought to profile lncRNAs from nasal mucosa telangiectasias of HHT1 and HHT2 patients [110], and identified 42 lncRNAs that were significantly dysregulated $(p<0.001)$, including TTLL11-IT1, LINC00667, HAR1B and LINC0032, compared to non-telangiectasial nasal mucosa from the same HHT patients. However, none of the dysregulated lncRNAs have been characterized. Bioinformatic analysis revealed that these lncRNAs were enriched in HHT-related pathways, including vasculogenesis and blood vessel morphogenesis and development (Figure 1). Further research is required to characterize the role these dysregulated lncRNAs may play in HHT pathogenesis.

\section{Conclusions and Future Research}

The observation of ncRNA dysregulation in ECs and PBMCs from patients with HHT suggests that they may play a role in the pathogenesis of HHT. Further characterization of ncRNAs in other cell types involved in HHT, including VSMCs, pericytes and mononuclear cells is necessary to more fully understand the pathogenetic mechanisms controlling the disease and its progression. 
To date, the targets and functions of only a small fraction of ncRNAs identified in humans have been rigorously explored. With further research, ncRNAs may prove to have both diagnostic and therapeutic applications for those with HHT.

Funding: Our HHT research was funded in part as a pilot project of the Brain Vascular Malformation Consortium (BVMC). The BVMC is supported by National Institutes of Health (NIH) grant U54 NS065705. The BVMC is part of the NIH Rare Disease Clinical Research Network (RDCRN), supported through collaboration between the NIH Office of Rare Diseases Research (ORDR) at the National Center for Advancing Translational Science (NCATS), and the National Institute of Neurological Disorders and Stroke (NINDS).

Acknowledgments: The authors would like to thank the staff at the Toronto HHT Centre at St. Michael's Hospital for their help in patient recruitment, and Si-Cheng Dai and Daniel Han from Western University and the University of Toronto, respectively, for editing.

Conflicts of Interest: The authors declare no conflict of interest.

\section{References}

1. Zarrabeitia, R.; Albiñana, V.; Salcedo, M.; Señaris-Gonzalez, B.; Fernandez-Forcelledo, J.-L.; Botella, L.-M. A review on clinical management and pharmacological therapy on hereditary haemorrhagic telangiectasia (HHT). Curr. Vasc. Pharmacol. 2010, 8, 473-481. [CrossRef] [PubMed]

2. McDonald, J.; Bayrak-Toydemir, P.; Pyeritz, R.E. Hereditary hemorrhagic telangiectasia: An overview of diagnosis, management, and pathogenesis. Genet. Med. 2011, 13, 607-616. [CrossRef] [PubMed]

3. Bayrak-Toydemir, P.; Mao, R.; Lewin, S.; McDonald, J. Hereditary hemorrhagic telangiectasia: An overview of diagnosis and management in the molecular era for clinicians. Genet. Med. 2004, 6, 175-191. [CrossRef] [PubMed]

4. Puente, R.Z.; Bueno, J.; Salcedo, M. Epidemiology of Hereditary Haemorrhagic Telangiectasia (HHT) in Spain. Hered. Genet. 2016, 05, 173. [CrossRef]

5. Clark, M.; Berry, P.; Martin, S.; Harris, N.; Sprecher, D.; Olitsky, S.; Hoag, J.B. Nosebleeds in hereditary hemorrhagic telangiectasia: Development of a patient-completed daily eDiary. Laryngoscope Investig. Otolaryngol. 2018, 3, 439-445. [CrossRef]

6. McAllister, K.A.; Grogg, K.M.; Johnson, D.W.; Gallione, C.J.; Baldwin, M.A.; Jackson, C.E.; Helmbold, E.A.; Markel, D.S.; McKinnon, W.C.; Murrell, J. Endoglin, a TGF-beta binding protein of endothelial cells, is the gene for hereditary haemorrhagic telangiectasia type 1. Nat. Genet. 1994, 8, 345-351. [CrossRef]

7. Johnson, D.W.; Berg, J.N.; Baldwin, M.A.; Gallione, C.J.; Marondel, I.; Yoon, S.J.; Stenzel, T.T.; Speer, M.; Pericak-Vance, M.A.; Diamond, A.; et al. Mutations in the Activin Receptor-Like Kinase 1 Gene in Hereditary Haemorrhagic Telangiectasia Type 2. Nat. Genet. 1996, 13, 189-195. [CrossRef]

8. Gallione, C.J.; Repetto, G.M.; Legius, E.; Rustgi, A.K.; Schelley, S.L.; Tejpar, S.; Mitchell, G.; Drouin, É.; Westermann, C.J.J.; Marchuk, D.A. A Combined Syndrome of Juvenile Polyposis and Hereditary Haemorrhagic Telangiectasia Associated with Mutations in MADH4 (SMAD4). Lancet 2004, 363, 852-859. [CrossRef]

9. Fernández-L, A.; Sanz-Rodriguez, F.; Blanco, F.J.; Bernabéu, C.; Botella, L.M. Hereditary hemorrhagic telangiectasia, a vascular dysplasia affecting the TGF-beta signaling pathway. Clin. Med. Res. 2006, 4, 66-78. [CrossRef]

10. Tual-Chalot, S.; Oh, S.P.; Arthur, H.M. Mouse models of hereditary hemorrhagic telangiectasia: Recent advances and future challenges. Front. Genet. 2015, 6, 1-25. [CrossRef]

11. Crist, A.M.; Lee, A.R.; Patel, N.R.; Westhoff, D.E.; Meadows, S.M. Vascular deficiency of Smad 4 causes arteriovenous malformations: A mouse model of Hereditary Hemorrhagic Telangiectasia. Angiogenesis 2018, 21, 363-380. [CrossRef] [PubMed]

12. Sabbà, C.; Pasculli, G.; Lenato, G.M.; Suppressa, P.; Lastella, P.; Memeo, M.; Dicuonzo, F.; Guanti, G. Hereditary hemorrhagic telangiectasia: Clinical features in ENG and ALK1 mutation carriers. J. Thromb. Haemost. 2007, 5, 1149-1157. [CrossRef]

13. Bernabéu, C.; Blanco, F.J.; Langa, C.; Garrido-Martin, E.M.; Botella, L.M. Involvement of the TGF- $\beta$ superfamily signalling pathway in hereditary haemorrhagic telangiectasia. J. Appl. Biomed. 2010, 8, 169-177. [CrossRef] 
14. Gallione, C.J.; Richards, J.A.; Letteboer, T.G.W.; Rushlow, D.; Prigoda, N.L.; Leedom, T.P.; Ganguly, A.; Castells, A.; Ploos van Amstel, J.K.; Westermann, C.J.J.; et al. SMAD4 mutations found in unselected HHT patients. J. Med. Genet. 2006, 43, 793-797. [CrossRef]

15. Cole, S.G.; Begbie, M.E.; Wallace, G.M.F.; Shovlin, C.L. A new locus for hereditary haemorrhagic telangiectasia (HHT3) maps to chromosome 5. J. Med. Genet. 2005, 42, 577-582. [CrossRef] [PubMed]

16. Bayrak-Toydemir, P.; McDonald, J.; Akarsu, N.; Toydemir, R.M.; Calderon, F.; Tuncali, T.; Tang, W.; Miller, F.; Mao, R. A fourth locus for hereditary hemorrhagic telangiectasia maps to chromosome 7. Am. J. Med. Genet. Part A 2006, 140A, 2155-2162. [CrossRef]

17. Albiñana, V.; Zafra, M.P.; Colau, J.; Zarrabeitia, R.; Recio-Poveda, L.; Olavarrieta, L.; Pérez-Pérez, J.; Botella, L.M. Mutation affecting the proximal promoter of Endoglin as the origin of hereditary hemorrhagic telangiectasia type 1. BMC Med. Genet. 2017, 18, 20. [CrossRef]

18. Kapranov, P.; Cheng, J.; Dike, S.; Nix, D.A.; Duttagupta, R.; Willingham, A.T.; Stadler, P.F.; Hertel, J.; Hackermuller, J.; Hofacker, I.L.; et al. RNA Maps Reveal New RNA Classes and a Possible Function for Pervasive Transcription. Science 2007, 316, 1484-1488. [CrossRef]

19. Lee, R.C.; Feinbaum, R.L.; Ambros, V. The C. elegans heterochronic gene lin-4 encodes small RNAs with antisense complementarity to lin-14. Cell 1993, 75, 843-854. [CrossRef]

20. Wightman, B.; Ha, I.; Ruvkun, G. Posttranscriptional Regulation of the Heterochronic Gene lin-14 by lin-4 Mediates Temporal Pattern Formation in C. Elegans. Cell 1993, 75, 855-862. [CrossRef]

21. Hammond, S.M. An overview of microRNAs. Adv. Drug Deliv. Rev. 2015, 87, 3-14. [CrossRef] [PubMed]

22. Bushati, N.; Cohen, S.M. microRNA Functions. Annu. Rev. Cell Dev. Biol. 2007, 23, 175-205. [CrossRef] [PubMed]

23. Ardekani, A.M.; Naeini, M.M. The Role of MicroRNAs in Human Diseases. Avicenna J. Med. Biotechnol. 2010, 2, 161-179. [CrossRef] [PubMed]

24. Ha, T.-Y. MicroRNAs in Human Diseases: From Cancer to Cardiovascular Disease. Immune Netw. 2011, 11, 135. [CrossRef]

25. Wang, H.; Peng, R.; Wang, J.; Qin, Z.; Xue, L. Circulating microRNAs as potential cancer biomarkers: The advantage and disadvantage. Clin. Epigenetics 2018, 10, 1-10. [CrossRef]

26. Dwivedi, S.; Purohit, P.; Sharma, P. MicroRNAs and Diseases: Promising Biomarkers for Diagnosis and Therapeutics. Indian J. Clin. Biochem. 2019, 34, 243-245. [CrossRef]

27. Salinas-Vera, Y.M.; Marchat, L.A.; Gallardo-Rincón, D.; Ruiz-García, E.; Astudillo-De la Vega, H.; Echavarría-Zepeda, R.; López-Camarillo, C. AngiomiRs: MicroRNAs driving angiogenesis in cancer (Review). Int. J. Mol. Med. 2019, 43, 657-670. [CrossRef]

28. De Rie, D.; Abugessaisa, I.; Alam, T.; Arner, E.; Arner, P.; Ashoor, H.; Åström, G.; Babina, M.; Bertin, N.; Burroughs, A.M.; et al. An integrated expression atlas of miRNAs and their promoters in human and mouse. Nat. Biotechnol. 2017, 35, 872-878. [CrossRef]

29. Kim, Y.K.; Kim, V.N. Processing of intronic microRNAs. EMBO J. 2007, 26, 775-783. [CrossRef]

30. Tanzer, A.; Stadler, P.F. Molecular evolution of a microRNA cluster. J. Mol. Biol. 2004, 339, 327-335. [CrossRef]

31. Ha, M.; Kim, V.N. Regulation of microRNA biogenesis. Nat. Rev. Mol. Cell Biol. 2014, 15, 509-524. [CrossRef] [PubMed]

32. Denli, A.M.; Tops, B.B.J.; Plasterk, R.H.A.; Ketting, R.F.; Hannon, G.J. Processing of primary microRNAs by the Microprocessor complex. Nature 2004, 432, 231-235. [CrossRef] [PubMed]

33. Zhang, H.; Kolb, F.A.; Jaskiewicz, L.; Westhof, E.; Filipowicz, W. Single processing center models for human Dicer and bacterial RNase III. Cell 2004, 118, 57-68. [CrossRef] [PubMed]

34. Khvorova, A.; Reynolds, A.; Jayasena, S.D. Erratum: Functional siRNAs and miRNAs Exhibit Strand Bias (Cell 115 (209-216)). Cell 2003, 115, 209-216. [CrossRef]

35. Jo, M.H.; Shin, S.; Jung, S.R.; Kim, E.; Song, J.J.; Hohng, S. Human Argonaute 2 Has Diverse Reaction Pathways on Target RNAs. Mol. Cell 2015, 59, 117-124. [CrossRef]

36. Ipsaro, J.J.; Joshua-Tor, L. From guide to target: Molecular insights into eukaryotic RNA-interference machinery. Nat. Struct. Mol. Biol. 2015, 22, 20-28. [CrossRef]

37. Xu, W.; Lucas, A.S.; Wang, Z.; Liu, Y. Identifying microRNA targets in different gene regions. BMC Bioinformatics 2014, 15, S4. [CrossRef]

38. Jonas, S.; Izaurralde, E. Towards a molecular understanding of microRNA-mediated gene silencing. Nat. Rev. Genet. 2015, 16, 421-433. [CrossRef] 
39. Chen, X.; Ba, Y.; Ma, L.; Cai, X.; Yin, Y.; Wang, K.; Guo, J.; Zhang, Y.; Chen, J.; Guo, X.; et al. Characterization of microRNAs in serum: A novel class of biomarkers for diagnosis of cancer and other diseases. Cell Res. 2008, 18, 997-1006. [CrossRef]

40. Hunter, M.P.; Ismail, N.; Zhang, X.; Aguda, B.D.; Lee, E.J.; Yu, L.; Xiao, T.; Schafer, J.; Lee, M.-L.T.; Schmittgen, T.D.; et al. Correction: Detection of microRNA Expression in Human Peripheral Blood Microvesicles. PLoS ONE 2010, 5. [CrossRef]

41. Mitchell, P.S.; Parkin, R.K.; Kroh, E.M.; Fritz, B.R.; Wyman, S.K.; Pogosova-Agadjanyan, E.L.; Peterson, A.; Noteboom, J.; O’Briant, K.C.; Allen, A.; et al. Circulating microRNAs as stable blood-based markers for cancer detection. Proc. Natl. Acad. Sci. USA 2008, 105, 10513-10518. [CrossRef] [PubMed]

42. Chim, S.S.C.; Shing, T.K.F.; Hung, E.C.W.; Leung, T.Y.; Lau, T.K.; Chiu, R.W.K.; Lo, Y.M.D. Detection and characterization of placental microRNAs in maternal plasma. Clin. Chem. 2008, 54, 482-490. [CrossRef] [PubMed]

43. Maqbool, R.; Hussain, M.U. MicroRNAs and human diseases: Diagnostic and therapeutic potential. Cell Tissue Res. 2014, 358, 1-15. [CrossRef]

44. Sohel, M.M.H. Circulating microRNAs as biomarkers in cancer diagnosis. Life Sci. 2020, $248,117473$. [CrossRef]

45. Khoury, S.; Tran, N. Circulating microRNAs: Potential biomarkers for common malignancies. Biomark. Med. 2015, 9, 131-151. [CrossRef] [PubMed]

46. Wang, J.; Chen, J.; Sen, S. MicroRNA as Biomarkers and Diagnostics. J. Cell. Physiol. 2016, 231, 25-30. [CrossRef]

47. Arroyo, J.D.; Chevillet, J.R.; Kroh, E.M.; Ruf, I.K.; Pritchard, C.C.; Gibson, D.F.; Mitchell, P.S.; Bennett, C.F.; Pogosova-Agadjanyan, E.L.; Stirewalt, D.L.; et al. Argonaute2 complexes carry a population of circulating microRNAs independent of vesicles in human plasma. Proc. Natl. Acad. Sci. USA 2011, 108, 5003-5008. [CrossRef]

48. Vickers, K.C.; Palmisano, B.T.; Shoucri, B.M.; Shamburek, R.D.; Remaley, A.T. MicroRNAs are transported in plasma and delivered to recipient cells by high-density lipoproteins. Nat. Cell Biol. 2011, 13, 423-435. [CrossRef]

49. Ismail, N.; Wang, Y.; Dakhlallah, D.; Moldovan, L.; Agarwal, K.; Batte, K.; Shah, P.; Wisler, J.; Eubank, T.D.; Tridandapani, S.; et al. Macrophage microvesicles induce macrophage differentiation and miR-223 transfer. Blood 2013, 121, 984-995. [CrossRef]

50. Glinge, C.; Clauss, S.; Boddum, K.; Jabbari, R.; Jabbari, J.; Risgaard, B.; Tomsits, P.; Hildebrand, B.; Kääb, S.; Wakili, R.; et al. Stability of Circulating Blood-Based MicroRNAs - Pre-Analytic Methodological Considerations. PLoS ONE 2017, 12, e0167969. [CrossRef]

51. Moldovan, L.; Batte, K.E.; Trgovcich, J.; Wisler, J.; Marsh, C.B.; Piper, M. Methodological challenges in utilizing miRNAs as circulating biomarkers. J. Cell. Mol. Med. 2014, 18, 371-390. [CrossRef] [PubMed]

52. Oerlemans, M.I.F.J.; Mosterd, A.; Dekker, M.S.; de Vrey, E.A.; van Mil, A.; Pasterkamp, G.; Doevendans, P.A.; Hoes, A.W.; Sluijter, J.P.G. Early assessment of acute coronary syndromes in the emergency department: The potential diagnostic value of circulating microRNAs. EMBO Mol. Med. 2012, 4, 1176-1185. [CrossRef] [PubMed]

53. Shovlin, C.L.; Guttmacher, A.E.; Buscarini, E.; Faughnan, M.E.; Hyland, R.H.; Westermann, C.J.J.; Kjeldsen, A.D.; Plauchu, H. Diagnostic criteria for hereditary hemorrhagic telangiectasia (Rendu-Osler-Weber syndrome). Am. J. Med. Genet. 2000, 91, 66-67. [CrossRef]

54. Latino, G.A.; Brown, D.; Glazier, R.H.; Weyman, J.T.; Faughnan, M.E. Targeting under-diagnosis in hereditary hemorrhagic telangiectasia: A model approach for rare diseases? Orphanet J. Rare Dis. 2014, 9, 1-10. [CrossRef]

55. Lupa, M.D.; Wise, S.K. Comprehensive management of hereditary hemorrhagic telangiectasia. Curr. Opin. Otolaryngol. Head Neck Surg. 2016, 25, 64-68. [CrossRef]

56. Dupuis-Girod, S.; Bailly, S.; Plauchu, H. Hereditary Hemorrhagic Telangiectasia: From Molecular Biology to Patient Care. J. Thromb. Haemost. 2010, 8, 1447-1456. [CrossRef]

57. Hanneman, K.; Faughnan, M.E.; Prabhudesai, V. Cumulative radiation dose in patients with hereditary hemorrhagic telangiectasia and pulmonary arteriovenous malformations. Can. Assoc. Radiol. J. 2014, 65, 135-140. [CrossRef] 
58. Zhang, Q.; Kandic, I.; Faughnan, M.E.; Kutryk, M.J. Elevated circulating microRNA-210 levels in patients with hereditary hemorrhagic telangiectasia and pulmonary arteriovenous malformations: A potential new biomarker. Biomarkers 2013, 18, 23-29. [CrossRef]

59. Chan, S.Y.; Loscalzo, J. MicroRNA-210: A unique and pleiotropic hypoxamir. Cell Cycle 2010, 9, 1072-1083. [CrossRef]

60. Bavelloni, A.; Ramazzotti, G.; Poli, A.; Piazzi, M.; Focaccia, E.; Blalock, W.; Faenza, I. Mirna-210: A current overview. Anticancer Res. 2017, 37, 6511-6521.

61. Fasanaro, P.; D’Alessandra, Y.; Di Stefano, V.; Melchionna, R.; Romani, S.; Pompilio, G.; Capogrossi, M.C.; Martelli, F. MicroRNA-210 modulates endothelial cell response to hypoxia and inhibits the receptor tyrosine kinase ligand ephrin-A3. J. Biol. Chem. 2008, 283, 15878-15883. [CrossRef] [PubMed]

62. Tabruyn, S.P.; Hansen, S.; Ojeda-Fernández, M.L.; Bovy, N.; Zarrabeitia, R.; Recio-Poveda, L.; Bernabéu, C.; Martial, J.A.; Botella, L.M.; Struman, I. MiR-205 is downregulated in hereditary hemorrhagic telangiectasia and impairs TGF-beta signaling pathways in endothelial cells. Angiogenesis 2013, 16, 877-887. [CrossRef]

63. Sun, Y.; Xiao, Y.; Sun, H.; Zhao, Z.; Zhu, J.; Zhang, L.; Dong, J.; Han, T.; Jing, Q.; Zhou, J.; et al. MiR-27a regulates vascular remodeling by targeting endothelial cells' apoptosis and interaction with vascular smooth muscle cells in aortic dissection. Theranostics 2019, 9, 7961-7975. [CrossRef]

64. Urbich, C.; Kaluza, D.; Frömel, T.; Knau, A.; Bennewitz, K.; Boon, R.A.; Bonauer, A.; Doebele, C.; Boeckel, J.N.; Hergenreider, E.; et al. MicroRNA-27a/b controls endothelial cell repulsion and angiogenesis by targeting semaphorin 6A. Blood 2012, 119, 1607-1618. [CrossRef] [PubMed]

65. Wang, Y.L.; Gong, W.G.; Yuan, Q.L. Effects of miR-27a upregulation on thyroid cancer cells migration, invasion, and angiogenesis. Genet. Mol. Res. 2016, 15, 1-10. [CrossRef] [PubMed]

66. Feng, L.; Shen, F.; Zhou, J.; Li, Y.; Jiang, R.; Chen, Y. Hypoxia-induced up-regulation of miR-27a promotes paclitaxel resistance in ovarian cancer. Biosci. Rep. 2020, 40. [CrossRef]

67. Tokar, T.; Pastrello, C.; Rossos, A.E.M.; Abovsky, M.; Hauschild, A.C.; Tsay, M.; Lu, R.; Jurisica, I. MirDIP 4.1-Integrative database of human microRNA target predictions. Nucleic Acids Res. 2018, 46, D360-D370. [CrossRef]

68. Shirdel, E.A.; Xie, W.; Mak, T.W.; Jurisica, I. NAViGaTing the micronome using multiple microRNA prediction databases to identify signalling pathway-associated microRNAs. PLOS ONE 2011, 6. [CrossRef]

69. Gandellini, P.; Profumo, V.; Casamichele, A.; Fenderico, N.; Borrelli, S.; Petrovich, G.; Santilli, G.; Callari, M.; Colecchia, M.; Pozzi, S.; et al. MiR-205 regulates basement membrane deposition in human prostate: Implications for cancer development. Cell Death Differ. 2012, 19, 1750-1760. [CrossRef]

70. Gregory, P.A.; Bert, A.G.; Paterson, E.L.; Barry, S.C.; Tsykin, A.; Farshid, G.; Vadas, M.A.; Khew-Goodall, Y.; Goodall, G.J. The miR-200 family and miR-205 regulate epithelial to mesenchymal transition by targeting ZEB1 and SIP1. Nat. Cell Biol. 2008, 10, 593-601. [CrossRef]

71. Wang, B.; Koh, P.; Winbanks, C.; Coughlan, M.T.; McClelland, A.; Watson, A.; Jandeleit-Dahm, K.; Burns, W.C.; Thomas, M.C.; Cooper, M.E.; et al. MiR-200a prevents renal fibrogenesis through repression of TGF- $\beta 2$ expression. Diabetes 2011, 60, 280-287. [CrossRef] [PubMed]

72. Fernandez-L, A.; Sanz-Rodriguez, F.; Zarrabeitia, R.; Pérez-Molino, A.; Hebbel, R.P.; Nguyen, J.; Bernabéu, C.; Botella, L.M. Blood outgrowth endothelial cells from Hereditary Haemorrhagic Telangiectasia patients reveal abnormalities compatible with vascular lesions. Cardiovasc. Res. 2005, 68, 235-248. [CrossRef] [PubMed]

73. Lebrin, F.; Goumans, M.-J.; Jonker, L.; Carvalho, R.L.C.; Valdimarsdottir, G.; Thorikay, M.; Mummery, C.; Arthur, H.M.; ten Dijke, P. Endoglin Promotes Endothelial Cell Proliferation and TGF- $\beta /$ ALK1 Signal Transduction. EMBO J. 2004, 23, 4018-4028. [CrossRef]

74. Ruiz-Llorente, L.; Albiñana, V.; Botella, L.M.; Bernabeu, C. Differential Expression of Circulating Plasma miRNA-370 and miRNA-10a from Patients with Hereditary Hemorrhagic Telangiectasia. J. Clin. Med. 2020, 9, 2855. [CrossRef] [PubMed]

75. Chen, X.P.; Chen, Y.G.; Lan, J.Y.; Shen, Z.J. MicroRNA-370 suppresses proliferation and promotes endometrioid ovarian cancer chemosensitivity to CDDP by negatively regulating ENG. Cancer Lett. 2014, 353, 201-210. [CrossRef]

76. Gu, Y.; Becker, V.; Zhao, Y.; Menger, M.D.; Laschke, M.W. miR-370 inhibits the angiogenic activity of endothelial cells by targeting smoothened (SMO) and bone morphogenetic protein (BMP)-2. FASEB J. 2019, 33, 7213-7224. [CrossRef] 
77. Wang, X.H.; Chen, L. MicroRNA-370 suppresses the retinal capillary endothelial cell growth by targeting KDR gene. Bratislava Med. J. 2017, 118, 202-207. [CrossRef]

78. Zhang, H.; Sun, X.; Hao, D. Upregulation of microRNA-370 facilitates the repair of amputated fingers through targeting forkhead box protein O1. Exp. Biol. Med. 2016, 241, 282-289. [CrossRef]

79. Zhang, S.; Song, G.; Yuan, J.; Qiao, S.; Xu, S.; Si, Z.; Yang, Y.; Xu, X.; Wang, A. Circular RNA circ_0003204 inhibits proliferation, migration and tube formation of endothelial cell in atherosclerosis via miR-370-3p/TGFßR2/phosph-SMAD3 axis. J. Biomed. Sci. 2020, 27, 1-17. [CrossRef]

80. Li, J.; Zhang, Y.; Zhao, Q.; Wang, J.; He, X. MicroRNA-10a influences osteoblast differentiation and angiogenesis by regulating $\beta$-catenin expression. Cell. Physiol. Biochem. 2015, 37, 2194-2208. [CrossRef]

81. Lee, D.Y.; Lin, T.E.; Lee, C.I.; Zhou, J.; Huang, Y.H.; Lee, P.L.; Shih, Y.T.; Chien, S.; Chiu, J.J. MicroRNA-10a is crucial for endothelial response to different flow patterns via interaction of retinoid acid receptors and histone deacetylases. Proc. Natl. Acad. Sci. USA 2017, 114, 2072-2077. [CrossRef] [PubMed]

82. Ors-Kumoglu, G.; Gulce-Iz, S.; Biray-Avci, C. Therapeutic microRNAs in human cancer. Cytotechnology 2019, 71, 411-425. [CrossRef]

83. Yang, G.; Zhang, W.; Yu, C.; Ren, J.; An, Z. MicroRNA let-7: Regulation, single nucleotide polymorphism, and therapy in lung cancer. J. Cancer Res. Ther. 2015, 11, C1-C6.

84. Castro, D.; Moreira, M.; Gouveia, A.M.; Pozza, D.H.; De Mello, R.A. MicroRNAs in lung cancer. Oncotarget 2017, 8, 81679-81685. [CrossRef] [PubMed]

85. Butz, H.; Rácz, K.; Hunyady, L.; Patócs, A. Crosstalk between TGF-B signaling and the microRNA machinery. Trends Pharmacol. Sci. 2012, 33, 382-393. [CrossRef]

86. Gordon, K.J.; Blobe, G.C. Role of transforming growth factor- $\beta$ superfamily signaling pathways in human disease. Biochim. Biophys. Acta Mol. Basis Dis. 2008, 1782, 197-228. [CrossRef]

87. Guerrero-Esteo, M.; Sanchez-Elsner, T.; Letamendia, A.; Bernabeu, C. Extracellular and cytoplasmic domains of endoglin interact with the transforming growth factor-beta receptors I and II. J. Biol. Chem. 2002, 277, 29197-29209. [CrossRef]

88. Goumans, M.-J.; Liu, Z.; ten Dijke, P. TGF- $\beta$ Signaling in Vascular Biology and Dysfunction. Cell Res. 2009, 19, 116-127. [CrossRef] [PubMed]

89. Hata, A.; Lagna, G. Deregulation of Drosha in the pathogenesis of hereditary hemorrhagic telangiectasia. Curr. Opin. Hematol. 2019, 26, 161-169. [CrossRef] [PubMed]

90. Lee, Y.; Ahn, C.; Han, J.; Choi, H.; Kim, J.; Yim, J.; Lee, J.; Provost, P.; Rådmark, O.; Kim, S.; et al. The nuclear RNase III Drosha initiates microRNA processing. Nature 2003, 425, 415-419. [CrossRef] [PubMed]

91. Han, J.; Pedersen, J.S.; Kwon, S.C.; Belair, C.D.; Kim, Y.K.; Yeom, K.H.; Yang, W.Y.; Haussler, D.; Blelloch, R.; Kim, V.N. Posttranscriptional Crossregulation between Drosha and DGCR8. Cell 2009, 136, 75-84. [CrossRef] [PubMed]

92. Rolando, C.; Erni, A.; Grison, A.; Beattie, R.; Engler, A.; Gokhale, P.J.; Milo, M.; Wegleiter, T.; Jessberger, S.; Taylor, V. Multipotency of Adult Hippocampal NSCs In Vivo Is Restricted by Drosha/NFIB. Cell Stem Cell 2016, 19, 653-662. [CrossRef] [PubMed]

93. Gromak, N.; Dienstbier, M.; Macias, S.; Plass, M.; Eyras, E.; Cáceres, J.F.; Proudfoot, N.J. Drosha regulates gene expression independently of RNA cleavage function. Cell Rep. 2013, 5, 1499-1510. [CrossRef]

94. Kuehbacher, A.; Urbich, C.; Zeiher, A.M.; Dimmeler, S. Role of Dicer and Drosha for endothelial microRNA expression and angiogenesis. Circ. Res. 2007, 101, 59-68. [CrossRef] [PubMed]

95. Jiang, X.; Wooderchak-Donahue, W.L.; McDonald, J.; Ghatpande, P.; Baalbaki, M.; Sandoval, M.; Hart, D.; Clay, H.; Coughlin, S.; Lagna, G.; et al. Inactivating mutations in drosha mediate vascular abnormalities similar to hereditary hemorrhagic telangiectasia. Sci. Signal. 2018, 11. [CrossRef]

96. Watterston, C.; Zeng, L.; Onabadejo, A.; Childs, S.J. MicroRNA26 attenuates vascular smooth muscle maturation via endothelial bmp signalling. PLoS Genet. 2019, 15. [CrossRef]

97. Miscianinov, V.; Martello, A.; Rose, L.; Parish, E.; Cathcart, B.; Mitić, T.; Gray, G.A.; Meloni, M.; Al Haj Zen, A.; Caporali, A. MicroRNA-148b Targets the TGF- $\beta$ Pathway to Regulate Angiogenesis and Endothelial-to-Mesenchymal Transition during Skin Wound Healing. Mol. Ther. 2018, 26, 1996-2007. [CrossRef]

98. Climent, M.; Quintavalle, M.; Miragoli, M.; Chen, J.; Condorelli, G.; Elia, L. TGF $\beta$ triggers miR-143/145 transfer from smooth muscle cells to endothelial cells, thereby modulating vessel stabilization. Circ. Res. 2015, 116, 1753-1764. [CrossRef] 
99. Cannavicci, A.; Zhang, Q.; Dai, S.-C.; Faughnan, M.E.; Kutryk, M.J.B. Decreased levels of miR-28-5p and miR-361-3p and increased levels of insulin-like growth factor 1 mRNA in mononuclear cells from patients with hereditary hemorrhagic telangiectasia. Can. J. Physiol. Pharmacol. 2019, 97, 562-569. [CrossRef]

100. Verhoeckx, K.; Cotter, P.; López-Expósito, I.; Kleiveland, C.; Lea, T.; Mackie, A.; Requena, T.; Swiatecka, D.; Wichers, H. The Impact of Food Bioactives on Health; Verhoeckx, K., Cotter, P., López-Expósito, I., Kleiveland, C., Lea, T., Mackie, A., Requena, T., Swiatecka, D., Wichers, H., Eds.; Springer International Publishing: Cham, Switzerland, 2015; ISBN 978-3-319-15791-7.

101. Post, S.; Smits, A.M.; Van Den Broek, A.J.; Sluijter, J.P.G.; Hoefer, I.E.; Janssen, B.J.; Snijder, R.J.; Mager, J.J.; Pasterkamp, G.; Mummery, C.L.; et al. Impaired recruitment of HHT-1 mononuclear cells to the ischaemic heart is due to an altered CXCR4/CD26 balance. Cardiovasc. Res. 2010, 85, 494-502. [CrossRef]

102. Peter, M.R.; Jerkic, M.; Sotov, V.; Douda, D.N.; Ardelean, D.S.; Ghamami, N.; Lakschevitz, F.; Khan, M.A.; Robertson, S.J.; Glogauer, M.; et al. Impaired Resolution of Inflammation in the Endoglin Heterozygous Mouse Model of Chronic Colitis. Mediators Inflamm. 2014, 2014, 1-13. [CrossRef]

103. Friedrich, C.C.; Lin, Y.; Krannich, A.; Wu, Y.; Vacanti, J.P.; Neville, C.M. Enhancing engineered vascular networks in vitro and in vivo: The effects of IGF1 on vascular development and durability. Cell Prolif. 2018, 51, e12387. [CrossRef] [PubMed]

104. Wang, X.; Dai, Z.; Wu, X.; Wang, K.; Wang, X. Distinct RNA transcriptome patterns are potentially associated with angiogenesis in Tie2-expressing monocytes. Gene 2016, 580, 1-7. [CrossRef]

105. Shi, X.; Teng, F. Down-regulated miR-28-5p in human hepatocellular carcinoma correlated with tumor proliferation and migration by targeting insulin-like growth factor-1 (IGF-1). Mol. Cell. Biochem. 2015, 408, 283-293. [CrossRef]

106. Xia, Q.; Han, T.; Yang, P.; Wang, R.; Li, H.; Zhang, J.; Zhou, X. MicroRNA-28-5p Regulates Liver Cancer Stem Cell Expansion via IGF-1 Pathway. Stem Cells Int. 2019, 2019, 1-16. [CrossRef] [PubMed]

107. Tsagakis, I.; Douka, K.; Birds, I.; Aspden, J.L. Long non-coding RNAs in development and disease: Conservation to mechanisms. J. Pathol. 2020, 250, 480-495. [CrossRef]

108. Jaé, N.; Dimmeler, S. Noncoding RNAs in Vascular Diseases. Circ. Res. 2020, 126, 1127-1145. [CrossRef]

109. Singh, K.K.; Matkar, P.N.; Quan, A.; Mantella, L.-E.; Teoh, H.; Al-Omran, M.; Verma, S. Investigation of TGF $\beta$ 1-Induced Long Noncoding RNAs in Endothelial Cells. Int. J. Vasc. Med. 2016, 2016, 1-12. [CrossRef]

110. Tørring, P.M.; Larsen, M.J.; Kjeldsen, A.D.; Ousager, L.B.; Tan, Q.; Brusgaard, K. Long non-coding RNA expression profiles in hereditary haemorrhagic telangiectasia. PLoS ONE 2014, 9, 90272. [CrossRef] [PubMed]

Publisher's Note: MDPI stays neutral with regard to jurisdictional claims in published maps and institutional affiliations.

(C) 2020 by the authors. Licensee MDPI, Basel, Switzerland. This article is an open access article distributed under the terms and conditions of the Creative Commons Attribution (CC BY) license (http://creativecommons.org/licenses/by/4.0/). 